UNPLUGGED

\title{
International Management, Should We Abandon the Myth of Cultural Hybridity? A Re-examination of the Contribution of Postcolonial and Decolonial Approaches
}

\author{
Hèla Yousfi* \\ Associate Professor, Université Paris-Dauphine - PSL Research University, CNRS, UMR 7088, DRM, 750 I 6 PARIS, France
}

\begin{abstract}
The postcolonial and decolonial approaches open the way for a rich analysis of the material and cultural conditions in which international management operates, is spread, interpreted, and implemented. They also offer food for thought on the possibilities, tensions, and resistance associated with reinventing alternative organizations more respectful of the dignity of all, while still providing knowledge that is socially and politically useful for oppressed and marginalized groups. Nevertheless, and despite their undeniable contribution to the theoretical development of critical approaches in international management, these perspectives are faced with challenges and difficulties in both intellectual and empirical terms. In this article, I suggest a series of ways forward, which might allow for the renewal of the critical fruitfulness of this intellectual and political project, crucial to face the contemporary challenges of international management.
\end{abstract}

In the colonies, the foreigner arriving from elsewhere imposed himself with the help of his cannons and his machines. Despite successful domestication, despite appropriation, the colonizer always remains a foreigner. It is not the factories, the estates, or the bank account which primarily characterize the 'ruling class.' The ruling species is first and foremost the outsider from elsewhere, different from the indigenous population, 'the others.' Franz Fanon

46 rance will be able to freely bring to Morocco civilization, wealth and peace." This is how, on November 19, 1911, the Petit Journal, a popular mass-circulation daily newspaper, referred to France's civilizing mission and justified the colonization of the Moroccan people. The accompanying illustration shows Marianne wearing a Phrygian bonnet and a tunic bearing the colors of France. She is depicted, head held high, well-lit, like a radiant sun, symbolizing peace and benevolence. She is disproportionately large in comparison with others around her. These broad shoulders allow to support her heavy burdens, and her generous chest makes her a fine nurturing mother. Tiny Moroccans are bowing down before her. Marianne offers instruction (the book) and techniques of 'civilization' (the plow), which procure 'wealth' (shown as abundance from which pieces of gold fall).
The civilizing mission characteristic of the colonial enterprise has its origin in the 'modernity project' born of Enlightenment philosophy. The modernity project assumes that the creative purpose is primary, and that this permits human beings to master nature, to evolve, and to ensure 'progress' by liberating themselves from archaic thought structures, from 'traditions.' We shift from a religious vision of the history of humanity to a secular vision marked by scientific models of evolutionism, favoring a perception of culture as a process of social development. In a European context, characterized by imperial expansion and European technological and industrial advancement, this vision of culture was used to assume a hierarchy, not only in political and economic terms but also in terms of cultural development among different societies and diverse social groups (Bauman, 1973).

Several decades later, immediately following the Second World War and the intensification of national liberation struggles, we find once again the same rhetoric but freshly redesigned, with the notion of 'development' in international economic relations. On January 20, 1949, American President Harry Truman explained, 'we must engage in a new audacious program, and use our scientific advancement and our industrial expertise to promote the improvement of living conditions and economic growth in underdeveloped regions.' It is the

*Corresponding author: Hèla Yousfi, Email: hela.yousfi@dauphine.psl.eu 
notion of 'underdevelopment,' which will be used in this discourse to characterize disadvantaged nations to which the Marshall Plan, with which Europe was familiar, should be extended. Until that point, this help had only been granted to a few countries in Latin America, as part of a global strategy to prevent communism. The concept of 'development' is very close to that of the 'civilizing mission.' We find the same elements in this quotation: American technical superiority would justify the 'civilizing mission,' which would also include the economic dimension, and a strong social and cultural overtone. As the economic dimension was considered to be less patronizing, it would be established gradually with, from the 1950s on, the appearance of a specific literature on development devoted to countries in this category, designated as the 'Third World' (Guillaumont, 1985).

It is in this intellectual and political context that the theory of modernization emerged. The theoreticians of modernization, Lewis (1954), McClelland (1964), and Parsons (1967), propose models with universal variables, which provide a binary model distinguishing modern societies from those labelled as traditional. They contend that the culture of so-called 'underdeveloped' countries constitutes an obstacle to development. The implicit hypothesis is that the technological, economic, and intellectual progress of 'victorious' nations should be emulated by the people of the 'poorest, least civilized' countries of the world. The legacy of the theory of modernization marks the works of Harbison and Myers (1959) and Farmer and Richman (1965) who contend that a convergence of socio-economic development in all countries would also result in the 'convergence of cultures' and management practices throughout the world, even if this type of universal convergence might take a number of decades. The application of management principles would not only enhance economic growth and overcome cultural resistance but also help democracy to take root.

The first critiques of the theory of modernization in the literature on economic development drew upon neo-Marxist doctrines and postcolonial and decolonial studies (Yousfi, 2010). These stressed the fact that the theory of modernization seriously neglected external political factors affecting societies, such as colonialism and imperialism, as well as new forms of economic and political domination. Neo-Marxist doctrines, such as the theory of dependence, emphasized the structure of the global economy as a source of underdevelopment (Amin, 1976; Arrighi, 1978; Wallerstein, 1976) and focused on how the relations between the 'center' and the 'periphery' explain the blockage of development in countries on the 'periphery,' and that this blockage is the fruit of the imperialism of countries at the 'center.' For their part, postcolonial and

1. The term 'underdevelopment' has been widely criticized by Marxist and postcolonial approaches, and it is no longer used. It was eventually replaced by the term 'Third World' and then by the 'Global South.' decolonial studies have centered their critical analysis on the discourse around universalism, historicism, and humanism, which they interpret as rhetoric, the goal of which is to legitimize both the colonial enterprise and development policies. Universalism is the discourse of 'western' colonial power, which defines itself as bearing a superior and universal ideal. Historicism, in recognizing irreversible progress in the human world, defends a linear trajectory of development, with the West as the model for 'underdeveloped' countries to follow (Escobar, 1995; Ferguson, 1990). And humanism supports the ethical and theoretical depiction not of all humans but rather of 'non-westerners' as inferior, and legitimizes the economic policy of 'under-development,' which would allow them access to the ranks of 'human beings.' Stuart Hall's formula in 1992 'I'Occident et les autres' is probably the best translation of this perspective.

In this article, after a brief digression to discuss the genealogy and state of the current social science debate on the contributions of postcolonial and decolonial approaches, I return to the way in which this literature has influenced critical approaches in international management. Then, I reference the tensions and theoretical and practical challenges, which postcolonial and decolonial approaches in international management must face. I conclude by outlining a series of ways forward, which might allow for the renewal of the critical fruitfulness of this intellectual and political project.

\section{Postcolonial and decolonial critiques: An epistemological stance, a theory or a political project?}

Postcolonial studies are an Anglophone school of thought born in the 1980s in Australian, British and North American universities, which analyzes the influences of British and French colonial legacies on colonized societies, as well as the persistent effects, even after independence, of the power structure governing relations between countries of the North and the South. This approach was inspired by a number of different sources, including the critique of orientalism by Edward Said, the Africanism of Yves Mudimébe, the literary critique of writers from India, from the Caribbean and Africa and the Indian group of 'subaltern' studies, such as Ranjit Guha, Gayatri Chakravorty Spivak and Homi Bhabha. This approach draws heavily upon the philosophical critique of so-called Western epistemology, in conjunction with the 'French Theory' and postmodern and poststructuralist anthropology and sociology of the 1980s. Largely inspired by the work of Michel Foucault, Gilles Deleuze, and Jacques Derrida, and also by psychoanalytical theories, such as that of Jacques Lacan on language and identity, the originality of the postcolonial school of thought lies in its contribution to filling a historical and philosophical vacuum, which is that of the analysis of the colonial 
fact in all its diversity. This approach takes on the mission of revealing the mechanisms of political and economic colonial domination, and also the colonial representations and epistemic violence of which the colonized were victims, as well as their survival, which remains problematic to this day.

In fact, all of these contributions, which are, moreover, quite disparate and which should not be considered as a single corpus as if this were a question of a homogeneous vision of the world or of a paradigm, oblige us to consider hitherto unseen questions, which must touch upon the ethnocentrism of modern European thought inherited from an intellectual tradition of the Enlightenment. Their central focus is a radical re-questioning of the self-proclaimed universalism of the Enlightenment tradition. While these works, largely tied to the Marxist and post-Marxist tradition, question the tendency of the dominant intellectual production to proclaim the validity of certain analytical categories independent of local cultures and historical specificities, they also aim to go beyond a certain form of Marxist universalism, which is suspected of suffering from the same intellectual blindness concerning the local social and cultural dynamics agitating societies of the South. They explain that notions of class, capitalism, and exploitation cannot be valid everywhere, as they cannot recognize the diversity of social, economic, and political relations in Europe, as well as in Africa or Asia (Chakrabarty, 2008).

Later, toward the end of the 1990s and the start of the 2000s, we witness the emergence of decolonial theories, theoretical genealogies which are rooted in South American Hispanic and Lusophone intellectual and popular history.These take up the postcolonial critiques and, while radicalizing their ambitions and significance (racist, capitalist, sexist, etc.), make the theorization of oppression a means of political struggle. This school of thought intends to overcome the ethnocentrism of the postcolonial critique, limited as it is to the field of reflection specific to the legacy of northern European empires of the 19th century, by reinstating the Latin American experience from the outset. The dark underside of modernity, according to the Argentinian philosopher Dussel (2009), neither begin with the Enlightenment, nor with the Industrial Revolution; it starts in 1492 with the pseudo-discovery of the Americas. Among those adopting this approach, we find the Argentinian semiologist Walter Mignolo, the Puerto Rican sociologist Ramon Grosfoguel, the Colombian anthropologist Arturo Escobar, and the Peruvian sociologist Aníbal Quijano.

Beyond the historical roots of decolonial studies in Latin American thought, this approach claims to differ from postcolonial studies in its focus on the indissociable character of modernity and coloniality introduced starting in 1492 (Boidin, 2009). The objective is to reveal the persistence of the global coloniality of power, knowledge, and being after decolonization. The notion of global coloniality of power refers to the complex and dynamic intertwining of economic phenomena and of sociocultural and political processes produced by patriarchal reproduction, colonialism, capitalism, and globalization (Mignolo, 2000). Later, the pioneers of feminist decolonial thought, Chandra Talpdade Mohanty, Maria Lugones, and many others, remind us that the world's colonial racialization is gendered. In other words, capitalist economic exploitation is a system that combines and exacerbates the colonial, social, sexual, and racial divisions of labor. Finally, decolonial studies differ from postcolonial studies, in that the former call for the recognition of an epistemic diversity through the rehabilitation of 'subaltern thinkers,' conceived as the central component of global modern or colonial decolonization, leading toward what the philosopher of Latin-American liberation Enrique Dussel calls 'transmodernity' (Grosfoguel, 2010).

In this respect, it is useful to remember that, while postcolonial and decolonial approaches owe a great deal to proponents of the French theory but also to intellectual, literary, and artistic trends, which focused on the colonial question in France in the 1950s, including Aimé Césaire and his discourse on colonialism, Albert Memmi (The Colonizer and the Colonized), and Franz Fanon (The Wretched of the earth or Black skin, White masks), the introduction of postcolonial and decolonial studies in French social science gave rise to three types of critiques: United States-centrism, Manichaeism, and essentialism. The work of Jean-François Bayart 'Les études postcoloniales: un carnaval académique,' published in 2010 , is, without doubt, the work most emblematic of the problematic reception of postcolonial and decolonial studies in France. Certain authors explain that this French resistance is inherent to the historicity of the French revolution, the unitary orientation of the 'one and indivisible' Republic, little inclined to recognize itself in multiculturalism, as the proponents of postcolonial studies complain. Others specify that French reticence to embrace postcolonial and decolonial studies instead signals the uniqueness of French colonial history and a different configuration of the academic field, which is, instead, invested in other traditions of critical research, inspired by Foucault and Bourdieu, or historical perspectives (Marie-Claude, 2007). This resistance clearly also explains the quasi-absence of these approaches from Francophone critical managerial literature.

The postcolonial and decolonial studies, however, remain fundamentally heterogeneous and do not call into question the flows and blending of the past heritage, prior and contemporary to colonization. The debates they engender concern not only identity and culture, nor even the marginalization of minority and racialized groups in Western societies. They are tied to identifying traces of a certain continuity in the forms of material and symbolic violence the origin of which can be found in the history of colonization and which are still manifest today in the treatment of dominated groups in Western societies but also in the relations between countries of the North and the South. There is really no one postcolonial or decolonial 
theory, but rather a series of places, authors, and conjunctures offering a critique of the effects of the colonial heritage, which was subsequently worked on and displaced by this question of the relationship between the challenges of decolonization and the tasks of political, economic, and intellectual emancipation of countries of the South. The aim of this eminently political intellectual project revolves around three dimensions: resistance to the dominant representations; a consideration of colonial history and its effects on the contemporary world, in terms of an examination of shared experience; and finally, the hope for reciprocal recognition, giving back to each one its own history, culture, and dignity.

\section{International management under the lens of postcolonial and decolonial approaches}

Postcolonial and decolonial approaches in international management perceived globalization with the hegemony of the American model as a colonization of knowledge and of the representation of what constitutes good management. They are interested in the way with which western epistemology has guided and constrained the knowledge production in organization theory by colonizing the depictions of organizational practices of non-Western countries (Banerjee \& Prasad, 2008; Cooke, 2004; Mir, 2003). Obviously, the celebrated 2003 work edited by Prasad, Postcolonial Theory and Organizational Analysis: A Critical Engagement, constitutes the pivotal moment for postcolonial approaches in management and organization. This book attempts to respond to a question, rarely posed in the discipline of management, that is, one concerning the consequences of modern western colonialism for both organizational practices and intellectual production in management. This school of thought is interested in a number of subjects, including the links between colonialism and industrialization, the depiction of the figure of the (colonized) worker as docile, the relations between organizations and colonial administration, the convergence of colonial and managerial ideologies, and the similarities between colonial regimes and international regimes as global systems of control.

In that respect, it is useful to recall that due to the domination of positivist approaches, the domain of international or intercultural management has been most resistant to the contribution of critical perspectives (Jack \& Westwood, 2009, p. $87 \mathrm{I}$ ). With the success of the American industrial system after the Second World War and its spread internationally, Americanization became synonymous with modernization, and the American management style was naturalized in managerial discourse and development policies (Cooke, 2004; Djelic, 1998; Kipping, Engwall, \& Üsdiken, 2008; Mir, 2003; Westwood \& Jack, 2007). It was only starting in the 2000s that a number of voices were raised in the English-speaking world to insist on the potential of critical research in this field. International management, therefore, is becoming an excellent laboratory for postcolonial approaches, notably in the Anglophone milieu. For example, it is a matter of exploring the role of new practices of contemporary imperialism, referred to as neo-colonial, which replace direct colonial occupation with an ever-expanding role for international institutions, such as the World Bank, the World Trade Organization (WTO), and the International Monetary Fund (IMF), in maintaining the economic and political dependence of countries of the South. Other studies have been interested in deconstructing such concepts as social responsibility or sustainable development to show the 'colonizing' ambition or 'domination' behind these instruments. These are considered as bearers of Western domination by multinationals who would like to assert their power and neutralize the resistance of local populations in the countries of the South (Gantman, Yousfi \& Alcadipani, 20I5).

Another trend in postcolonial management studies has focused on a critical examination of the celebration of diversity, inclusion, and multiculturalism as just and equitable principles of international management (Kaasila-Pakanen, 20 I 5). Starting from the hypothesis that the enterprise is, first and foremost, a space historically subject to power relations or domination, multiculturalism underlying the notion of diversity is studied from this perspective as an instrument of control inherent to broader institutional power structures. Cultural diversity management is perceived as a discourse produced by the dominant actors and would, above all, resemble a mechanism to control minorities. Under this light, multiculturalism, which is a corollary of diversity management, is suspected of reifying simplistic and reductionist categories of culture and identity, thus reinforcing inequalities (Jack, 20।5).

The postcolonial critique, therefore, reveals the persistence of subtle and implicit references of control and domination in the discourse around cultural diversity, which run counter to attitudes of tolerance and equality of treatment advocated by the classic perspectives on diversity management. The emphasis on the benefits of managing cultural diversity, the importance of managers' intercultural skills, and management measures allowing for 'inclusion,' which abound in this dominant literature are, ultimately, not that surprising, as these are much more manageable options than tackling the difficult work of the decolonization of knowledge and denouncing relationships of domination or even disturbing the established hegemonic order. In summary, postcolonial approaches in international management have shown that despite the public international management discourse according to which the primary issue is a recognition of the other, the categories used may act as technologies of control, employed to 'discipline' and manage the tensions and contradictions stemming from differences, and as a result, serve to neutralize the subversive potential for resistance by those being subjugated.

Shortly thereafter, a number of studies more influenced by the new contributions of decolonial theories, in particular by 
Brazilian and Argentinian researchers, radicalized the project and adopted as an agenda for the decolonization of knowledge in international management (Alcadipani \& Faria, 20l4; Ibarra-Colado, 2006). They denounced the hegemony of American managerial literature, which sees the importation of American management knowledge as the only way to strengthen the economies of the countries of the South and improve the productivity of local enterprises (Alcadipani, Khan, Gantman, \& Nkomo, 2012). They adopt as their mission the deconstruction of the self-proclaimed universality of the Western, notably American, managerial literature through a political project favoring intellectual production coming from the South. From this perspective, Jack and Westwood (2009) speak of the importance of 'decolonizing' international and intercultural management's research methodologies by emphasizing reflexivity and the need to rehabilitate indigenous research and methodologies in order to avoid American and European ethnocentrism (Dar, 20 I8; Gantman et al., 20 I5).

Now these studies were soon confronted with two fundamental tensions. The first concerned the material and symbolic difficulty associated with a number of centuries of economic, political, and intellectual colonization preventing 'subaltern and indigenous' people from speaking for themselves (Seremani \& Clegg, 2016). Besides the intellectuals of the diaspora living in the North, a very few authors from the South are cited in organizational studies, including critical perspectives. This absence can be explained by the ethnocentrism of the assessment frameworks used by the dominant Western journals in the management field, as well as by the lack of financial means in the countries of the South, crucial for intellectual production and its dissemination. Consequently, it is not surprising to observe that postcolonial and decolonial perspectives have especially flourished in Brazil, India, and South Africa, relatively economically and politically powerful countries.

The second tension relates to the difficulty of constructing adequate criteria for identifying so-called 'indigenous' sites and/ or methodologies in a world where traces of the hegemonic undertaking of globalization are ubiquitous. And the central question raised in the postcolonial and decolonial school of thought becomes: how one can recognize cultural roots while avoiding essentialism, and how one can take into account the cultural melange or mixture, without imposing colonial categories when one considers various ways of organizing and working and different trajectories to construct an identity in the countries of the South (Islam, 20 I2; Nkomo, 20 I I)?

\section{Hybridity: A miraculous antidote to essentialism?}

The response to this question is found in the emergence of hybridity as a new concept and an antidote to essentialism. Largely inspired by the pioneering work of Homi Bhabha
(1984, 1994, 1996), the terms 'hybridity' and 'hybridization' have become key concepts in postcolonial and decolonial approaches, and are increasingly used in the organizational literature to examine the effects of the 'colonial' encounter on the transformation of management practices in countries of the South (Dar, 2018; Frenkel, 2006, 2008; Seremani \& Clegg, 20 I 6; Yousfi, 20 I 3). Contrary to Said (1979), who clearly distinguishes between the colonizer and the colonized, Bhabha considers the reciprocal effects of the colonizer on the colonized and vice versa within the colonial encounter. His concept of the 'third space of enunciation' positions hybridity as a transformative site within which the colonizer and the colonized are presented with new possibilities to describe the identity of Self and of the Other, and to invent new forms of political agency and of subversion (Parry, 1994). Imposed western knowledge is combined with different indigenous knowledge, leading to the creation of a hybrid version, which simultaneously indicates the effect of the dominant power and the resistance to it. From this viewpoint, the 'colonized' are not satisfied with merely importing western management knowhow; they are capable of resisting creatively and of subtly subverting the knowledge imposed on them by the 'colonizers,' thus blurring the binary distinctions between the western and local discourse.

Consequently, in international management, a number of authors have explored hybridization as a recurrent phenomenon when American management knowledge is confronted with local realities (Alcadipani \& Rosa, 201 I; Frenkel, 2005). Contrary to approaches based on translation (Czarniawska \& Sevón, 1996; Doorewaard \& Van Bijsterveld, 200I), neo-institutional (Kostova \& Roth, 2002; Zeitlin \& Herrigel, 2000), and intercultural approaches (Jackson, 2002; Tayeb, 200I), which have contributed in various ways to the reassessment of the hypothesis of homogenization, the postcolonial and decolonial perspectives have the significant merit of being able to clarify the dynamics of power or domination within the global system, all while considering issues of production and diffusion of western management and organizational knowledge in the countries of the South (Cooke, 2004; Prasad, 2003). Moreover, the mobilization of hybridity/hybridization would reveal that western and non-western borders are profoundly ambivalent constructs. As momentary and simultaneous places and expressions of the past and of the present, of inclusion and exclusion, of difference and of similarity, organizations become the new sites of disrupted borders.

Applied to intercultural management, the notions of hybridity and ambivalence advance more complex conceptualizations of the cultural difference as hybrid and fluid, always evolving. These notions would refashion organizational actors' identities, classically homogenized and reified in multiple, mobile, and provisional constructions, more precisely adapted to the living conditions and learning inherent in the vagueness of a global world in transformation. Now, while the concept of 
'hybridity' is seductive because it offers a framework, which has radically revisited intercultural approaches (replacing the hypothesis of cultural domination and/or or cultural essentialism with mutual contamination, the subversion and ambivalence characterizing contacts between cultures), it raises a number of theoretical and empirical challenges. Here, we distinguish two types of critiques. An initial series of critiques question the uses of the notion of hybridity in the managerial literature. A second series of more radical critiques question the relevance of the concept of hybridity in grasping the issues of power/domination that shape North-South relations today.

Critiques bearing on the notion of hybridity highlight the fact that its noncritical and decontextualized transposition could be problematic, since it risks neglecting the role played by historical and cultural contexts from which this phenomenon of hybridity emerges (Lo, Khoo, \& Gilbert, 2000; Werbner, 200 I). A contextualized approach to the process of hybridization in the countries of the South should take into account the fact that the process of Americanization was preceded by previous European colonial efforts to introduce their own models of productivity into the framework of the colonial mission (Frenkel \& Shenhav, 2003; Gantman \& Parker, 2006). Furthermore, the diversity of trajectories and experiences of processes of managerial hybridization in the countries of the South, the local historical power dynamics, and the array of local cultural meanings that shape knowledge, identities, and hybrid practices all remain largely unexplored (Yousfi, 20 I4).

A second series of critiques concern the conceptualization of culture inherent in the notion of hybridity. Hybridity in Bhabha's sense, with its focus on the effects of the colonial encounter, conveys the idea that the formation of identity is not limited to assumptions about national or other distinctions and considers culture as a malleable, dynamic, and adaptable social fact. From this perspective, any cultural continuity over long periods of time is rejected, since it implicitly presupposes the absence of a capacity for collective and individual agency, critical for changing social structures. Thus, although the tradition/modernity dichotomy inherent to the modernity project is radically criticized in postcolonial and decolonial approaches, it is reproduced in the priority given to 'individual agency' and 'social transformation,' and also in the implicit hypothesis according to which cultural continuity is supposed to impede progress. However, empirically, we find evidence of both widespread cultural change and stability in distinct cultural references (Yousfi, 2010).

Furthermore, theories celebrating hybridity as the antidote to cultural essentialism ignore the fact that national cultures are also, for the actors themselves, the matrices of ethical values and shared references shaping the way in which they perceive and may resist domination (Dupuis, Davel, \& Chanlat, 2007; D'Iribarne, 2009; Werbner, 200 I). Neither do they take into account the fact that although cultures change over time, certain forms of continuity associated with what today seem rather outmoded concepts, such as 'the spirit of a nation' (Montesquieu, 1748), 'national character' (Weber, 1905), and 'a world of avatars' (Geertz, 1973), may persist and could prove indispensable to better comprehending the way in which the heterogeneity of values or of social groups in a given society is expressed in more stable cultural references and shapes the relationship between culture and individual agency. Along these lines, d'Iribarne (2003) builds on the work of Bloch (1939), highlighting the diversity of conceptions of the free man (as opposed to the serf) in medieval Europe, and reveals traces of this in the modern world. He brings to the fore the existence of different conceptions of liberty in Anglophone, German, and French milieus, largely due to the legacy of visions of the free man dating back to these societies' pre-democratic past. These various national cultural conceptions of liberty produce their own forms of domination, transgression, and resistance based on more stable references and judgment criteria (Yousfi, 20|0).

The most radical critique of the notion of hybridity comes from Ajari (2019), the author of 'La dignité ou la mort, Ethique et politique de la race.' To that celebrated claim of Homi Bhabha that 'the way we conceptualize difference is important,' Norman Ajari responds that it is the daily realty of death experienced by subaltern groups, which produces the black person or the Muslim and not sociological conceptualizations and essentializing discourse. He points to the limitations of the theoretical sequence characterized by a radical anti-essentialism, opened up by French philosophy in the latter part of the twentieth century (Derrida, Foucault, and Deluze) and developed in the globalized university through a variety of theoretical initiatives under the labels of 'poststructuralism,' 'deconstruction,' or 'postmodernity.' He explains that the socially constructed character of race or identity, broadly established and admitted in poststructuralist and/or postcolonial critiques, is ineffective when faced with the spectacle of mutilated bodies, corpses floating in the Mediterranean or countless humiliations and the daily exploitation of the bodies of immigrants or workers in the countries of the global South. Reconnecting with the little-known history of the radical thought of black worlds, he demonstrates eloquently and in great details the fact that it is the violence of structural and historic international inequality, which produces race and not sociological articles.

For him, the insistence of deconstruction theories on the necessity of abolishing antagonistic political polarities by means of 'hybridity' weakens the critique itself just where it claims to be putting it into action. According to Norman Ajari, poststructuralist discourse on the fluidity of identities and the malleability of cultures only leads to a sort of narcissism of inexistence, in light of which the more political agents are biddable, not classifiable, and hazy, the more the discourse of deconstruction provides them the capacity to act. Whether they are 
promoting assimilation into Western societies or an African revaluation, the politics of identities and representations in vogue in recent decades have flourished as a result of the same misreading of life and death questions, which has made a brutal return with the Covid-19 crisis and the 'Black lives matter' movement. These policies remain powerless before the spectacle of death and the exploitation of inferiorized and racialized groups. And the Franco-Algerian philosopher Seloua Luste Boulbina best summarizes this contradiction:

"Michel Foucault was merely a traveler in Brazil and not a resident, a distinguished guest and not an irregular migrant, a white man and not a black woman. Clearly, this is why he was dreaming, writing of not having a face, or of losing his face (...). For the resident, the irregular migrant, the black woman, not having a face is not an ideal or a dream, it is an experience, a reality, a nightmare. So, on the contrary, there are those who express themselves to have a face." (Boulbina, 2008, p. 83)

\section{Conclusion}

Together, these postcolonial and decolonial perspectives that should not be seen as a homogeneous body of work or as a unified paradigm oblige us to consider new questions, which cannot leave untouched dominant positivist theories or classical critical theories. These perspectives claim that the dominant cultural and intellectual production is caught up in injustices of contemporaneity, of the future, and of the past by recognizing the impact of the colonial enterprise on the violent spread of modernity, as well as on the rupture or mutilation of local theoretical and empirical and/or indigenous knowledge. The importance of the contributions presented here resides in their promise to contribute to a growing awareness of common historical processes, of cultural reciprocity, and of diasporic tendencies of the globalizing world around more complex and multiple conceptualizations of domination or power relations, of paths of resistance and their effects on the transformations of current social, political, and economic relationships.

In international management, postcolonial and decolonial studies reveal the unconscious references buried in organizational discourse and practice, which claim to be pluralist, multicultural, and inclusive, and which are deployed to neutralize the eruption of the difference and resistance with which any intellectual and political hegemony is confronted. These postcolonial and decolonial analyses open the way for a reflection on the material and cultural conditions in which management operates, is spread, interpreted, and applied, and offers food for thought on the possibilities, tensions, and resistance associated with reinventing alternative organizations more respectful of the dignity of all, while still providing knowledge that is intellectually, socially, and politically useful for oppressed and marginalized groups. Nevertheless, and despite their undeniable contribution to the theoretical development of critical interpretations in international management, these perspectives must engage in dialogues on three key questions, which are becoming urgent, in both intellectual and empirical terms, and will further their development as analytical grids of contemporary challenges of international management:

First, they tend to stem from literary analysis, neglecting the material structure in which the discourse is produced. Postcolonial and decolonial studies are less concerned with practices that would be documented by fieldwork or archives than with the discourse and representations from which they dissert and even extrapolate in a sometimes, abusive fashion. Thus, postcolonial and decolonial inspired studies in international management limit themselves to discourse rather than effective practices, making an exploration of the ambivalence of phenomena at play in international encounters impossible. They are reduced to a reflective project, imposing a precise vocabulary on those who wish to employ it, and few approaches examine the way in which the dominant discourse concretely impacts local actors' practices and the way they resist and reinvent management methods imposed on them. While rehabilitation of power or domination relationships in the analysis of discourse in international management is beneficial in postcolonial and decolonial approaches, the concrete effects of these power relationships on practices are largely ignored. Efforts to provide for further exploration of the material, political, and economic structure, in which the hegemonic discourse in international management is inscribed, as well as of the managerial or organizational practices, which emerge from it, are sorely needed.

Second, there is a classic tension between 'the particular' and 'the universal' in postcolonial and decolonial approaches. The focus of these approaches on the perpetual construction of cultures does not allow us to grasp the way with which national cultures produce their own forms of domination, transgression, and resistance based on cultural references and more stable judgment criteria. Consequently, critical perspectives in international management should be developed to better take into account the interaction between (I) conscious, intersubjective, and political processes of reinterpretation and negotiation of imported practices; and (2) all the less negotiable and more stable realms of local cultural meanings. Moreover, it is this research path, from an enhanced anthropological perspective (Geertz, 1973; Ibn Khaldûn, 1967; Mauss, 1968), which will allow us to move away from both the glorification of what is local and the posture of denunciations, both of which are certainly useful but insufficient to truly grasp the conditions of economic and political transformation in countries of the South, while recognizing the ambivalent effects of American hegemonic discourse (Yousfi, 2014). It is less a matter of exploring the hybridity associated with the culture or identity, which would emerge from the colonial encounter than of 
working with a heightened awareness of the situation in which the translation or appropriation of formations of political and economic, colonial and post-colonial history in an anthropological and political context is always unique.

Third, the question of the transformative scope of this eminently political intellectual project has arisen. The concern with anti-essentialism in conjunction with the weight of the myth of modernity underlying most of these postcolonial and decolonial perspectives makes it difficult to analyze the relationship between the individual agency firmly entrenched in the project of modernity and the impact of structures of political and economic domination (Giddens, 1984). A persistent question in most postcolonial and decolonial studies is that of the balance to be found between a universalizing position, which flatly refuses to recognize the colonial period as a core foundation of colonized and colonizing societies, while avoiding consigning the indigenous peoples to a fantasy colonial condition. The responses to this, as mentioned previously, varied between two tendencies: that which focuses on international management as a combination of controls integrated in mutually constitutive material and discursive structures of international management at the risk of minimizing the agency of oppressed or subaltern groups.

And this comes from works on hybridity, which claim that employees from 'subaltern' groups are not passive receptacles of control, but rather, as actors, they reflect on this and act in such a way as to more or less conform, and through their reflections and actions, they can eventually create a space for their own micro-emancipation. From this perspective, while the stake is an expression of anti-essentialism aiming to deconstruct social and political determinism through insistence on micro-processes of emancipation, the risk is great of seeing the first political ambition of postcolonial and decolonial studies, a radical reassessment of power or domination relationships, relegated to the back burner. Obviously, Norman Ajari's suggestion (2019) to consider the question from the angle of dignity offers an alternative path to critical analysis.

Largely inspired by Franz Fanon and his concept of sovereignty-dignity, he reminds us that there is no dignity without power, and calls for replacing the ethics of recognition underlying the concepts of integration, inclusion, or multiculturalism, popularized by European moral philosophy, of which Hegel was the most emblematic figure, with a decolonial theory of dignity. This cannot be deciphered simply according to the principles of a moral law, the goal of which would be to render the domination and exploitation imperceptible; it can only proceed from historical and relational ethics. According to him, only a theory of dignity capable of putting back at the heart of the debate the material living conditions of subaltern individuals, forms of 'life-death' and the history of political, artistic, and intellectual revolts led by blacks and oppressed groups to impose their denied humanity that we may decipher the ongoing liberation processes. It is this relational and historical ethics of dignity that one is able to see in the processes of resistance led by oppressed groups against the dominant groups' moral norms of recognition. Under this light, authentic recognition comes from self-affirmation of the dignity of oppressed groups, forcing the dominant society to break with traditional modalities of recognition.

Finally, the aim of postcolonial and decolonial perspectives in international management consists less of explaining the world and providing instruments directly adapted to action than of acquiring sufficient understanding to provide the actors the essential keys to interpret their experience. However, these perspectives may be of some practical use since, like psychanalysis, in explaining particular behavior and its consequences depending on the case, they may lead to the modification of this behavior and/or its persistence. Postcolonial and decolonial perspectives were certainly not intended to cure society's ills. Yet, taking note of the effects produced by the malaise resulting from major political, intellectual, and historical reshuffle following the - interminable - end of empires, and the paths of resistance at work may suggest a fruitful point of view with respect to the conditions of disalienation of a particular era. From a theoretical viewpoint, the challenge is, thus, to substitute for the fluidity of hybridity in international management, the more complex question of the coexistence of a number of different temporalities and subjectivities stemming from political, economic, and epistemic violence in the international encounter. From a political perspective, the issue is to substitute for the question of inclusion and cultural diversity the question - certainly riskier for the dominant power - of the destruction of the political, economic, and symbolic order, enabling individuals, groups, and peoples, long and methodically oppressed and exploited, to recover their dignity.

\section{References}

Ajari, N. (2019). La Dignité ou la mort: Éthique et politique de la race. La Découverte.

Alcadipani, R. \& Faria, A. (2014). Fighting Latin American marginality in international business. Critical Perspectives on International Business, 10(1-2), I07-1 |7. doi: I0. I 108/cpoib- I |-2013-0047

Alcadipani, R., Khan, F. R., Gantman, E. \& Nkomo, S. (20I2). Southern voices in management and organization knowledge. Organization, I 2(2), I 3 I|43. doi: |0. | |77/| 3505084 | |431910

Alcadipani, R. \& Reis Rosa, A. (20I I). From grobal management to glocal management: Latin American perspectives as a counter-dominant management epistemology. Canadian Journal of Administrative Sciences, 28(4), 453-466. doi: 10.1002/cjas. 165

Amin, S. (1976). Unequal development: An essay on the social formations of peripheral capitalism. Harvester Press.

Arrighi, G. (1978). The geometry of imperialism: The limits of Hobson's paradigm. NLB. 
Banerjee, S. B. \& Prasad, A. (2008). Introduction to the special issue on "Critical reflections on management and organizations: A postcolonial perspective." Critical Perspectives on International Business, 4(2/3), 90-98. doi: I0.1 I 08/1742204081 0869963

Bauman, Z. (1973). Culture as praxis. Routledge.

Bhabha, H. (1984). Of mimicry and man:The ambivalence of colonial discourse. October, 28, 125-133. doi: 10.2307/778467

Bhabha, H. (1994). The location of culture. Routledge.

Bhabha, H. (1996). Culture's in-between. In S. Hall \& P. du Gay (Eds.), Questions of cultural identity (pp. 53-60). Sage.

Bloch, M. (1939). La société féodale. Albin Michel, (1968 [1939]).

Boidin, C. (2009). Études décoloniales et postcoloniales dans les débats français. Cahiers des Amériques Latines, 62, I29-| 40. doi: I0.4000/cal. 1620

Boulbina, S. L. (2008). Le singe de Kafka et autres propos sur la colonie. Sens Public.

Chakrabarty, D. (2008). Provincializing Europe: Postcolonial thought and historical difference. Princeton University Press.

Cooke, B. (2004). The managing of the (third) world. Organization, I I (5), 603-629. doi: 10.1 1 177//350508404044063

Czarniawska, B. \& Sevón, G. (Eds.) (1996). Translating organizational change. De Gruyter.

Dar, S. (2018). De-colonizing the boundary-object. Organization Studies, 39(4), 565-584. doi: I 0.1 177/0170840617708003

D'Iribarne, P. (2003). Trois figures de la liberté. Annales. Histoire, Sciences Sociales, 58(5), 953-978. doi: I $10.1017 / 50395264900018084$

D'Iribarne, P. (2009). Conceptualising national cultures: An anthropological perspective. European Journal of International Management, 3(2), 6. doi: I 0.1504/EJIM.2009.024320

Djelic, M-L. (1998). Exporting the American model: The post-war transformation of European business. Oxford University Press.

Doorewaard, H. \& Van Bijsterveld, M. (200I). The Osmosis of ideas: An analysis of the integrated approach to IT management from a translation theory perspective. Organization, 8(I), 55-76. doi: I0.1 I77/ | 35050840181004

Dupuis, J-P., Davel, E. \& Chanlat, J-F. (2007). Culture and development, the continuing tension between modern standards and local contexts, Culture, Institutions and development, New insights Into an Old debate (pp. 20-64). Routledge.

Dussel, E. (2009). Pour un dialogue mondial entre traditions philosophiques. Cahiers des Amériques Latines, 62(2009/3), III-127. doi: 10.4000/ cal. 1619

Escobar, A. (1995). Encountering development: The making and unmaking of the third world. Princeton University Press.

Farmer, R. N. \& Richman. B. N. (1965). Comparative management and economic progress. Homewood.

Ferguson, J. (1990). The anti-politics machine: Development, depoliticization, and bureaucratic power in Lesotho. CUP Archive.

Frenkel, M. (2005). The politics of translation: How state-level political relations affect the cross-national travel of management ideas. Organization, |2(2), 275-30 I. doi: | 0.1 | 177//35050840505 | 19 |

Frenkel, M. (2006). From binarism back to hybridity: A postcolonial reading of management and organization studies. Organization Studies, 27(6), 855-876. doi: I0.1 I 177/0 I70840606064086

Frenkel, M. (2008). The multinational corporation as a third space: Rethinking international management discourse on knowledge transfer through Homi Bhabha. Academy of Management Review, 33(4), 924-942. doi: I0.5465/amr.2008.34422002

Frenkel, M. \& Shenhav, Y. (2003). From Americanization to colonization:The diffusion of productivity models revisited. Organization Studies, 24(9), |537-|56 | doi: | 0.1 | 77//0 |70840603249006
Gantman, E. R. \& Parker, M. (2006). Comprador management?: Organizing management knowledge in Argentina (1975-2003). Critical Perspectives on International Business, 2( I),25-40. doi: I 0. I I 08/ I 74220406 I 0644 | 44

Gantman, E. R., Yousfi, H. \& Alcadipani, R. (2015). Challenging Anglo-Saxon dominance in management and organizational knowledge. Revista de Administração de Empresas, 55(2), 6. doi: 10.1590/S0034-759020150202

Geertz, C. (1973). The interpretation of cultures. Basic Books.

Giddens, A. (1984). The constitution of society: Outline of the theory of structuration. University of California Press.

Grosfoguel, R. (20|0). Vers une décolonisation des « uni-versalismes » occidentaux : le « pluri-versalisme décolonial », d'Aimé Césaire aux zapatistes. In A. Mbembe (Ed.), Ruptures postcoloniales: Les nouveaux visages de la société française (pp. | 19-138). La Découverte.

Guillaumont, P. (1985). Economie du développement: Dynamique interne du développement (Vol. 2). Presses Universitaires de France-PUF.

Hall, S. (1992). The West and the rest: Discourse and power. In T. D. Gupta, C. E. James, C. Andersen, G-E. Galabuzi \& R. C. A. Maaka (Eds.), Race and racialization (2nd ed., pp. 85-95). Canadian Scholars.

Harbison, F. \& Myers, C. A. (1959). Management in the industrial world: An international analysis. McGraw-Hill.

Ibarra-Colado, E. (2006). Organization studies and epistemic coloniality in Latin America:Thinking otherness from the margins. Organization, 13(4), 463-488. doi: 10.1 177//35050840606585 |

Ibn Khaldûn, A. (1967). Discours sur l'histoire universelle (al-Muqaddima). Annales, 25(3), 754-755.

Islam, G. (2012). Can the subaltern eat? Anthropophagic culture as a Brazilian lens on post-colonial theory. Organization, 19(2), 159-180. doi: | 0.1 | 177/| 3505084 | | 429396

Jack, G. (20 I5). Advancing postcolonial approaches in critical diversity studies. In R. Bendl, I. Bleijenbergh, E. Henttonen \& A. J. Mills (Eds.), The Oxford handbook of diversity in organizations (pp. 153-174). Oxford University Press.

Jack, G. \& Westwood, R. (2009). International and cross-cultural management studies: A postcolonial reading. Springer. doi: I 0. I057/978023024844 I

Jackson, T. (2002). The management of people across cultures:Valuing people differently. Human Resource Management, 4I (4), 455-475. doi: 10.1002/hrm. 10054

Kaasila-Pakanen, A-L. (20I5). A postcolonial deconstruction of diversity management and multiculturalism. In R. Bendl, I. Bleijenbergh, E. Henttonen \& A. J. Mills (Eds.), The Oxford handbook of diversity in organizations (pp. 175-194). Oxford University Press.

Kipping, M., Engwall, L. \& Üsdiken, B. (2008). Preface:The transfer of management knowledge to peripheral countries. International Studies of Management and Organization, 38(4), 3-16. doi: 10.2753/ IMO0020-8825380400

Kostova, T. \& Roth, K. (2002). Adoption of an organizational practice by subsidiaries of multinational corporations: Institutional and relational effects. Academy of Management Journal, 45(I), 215-233. doi: 10.2307/3069293

Lewis, W. A. (1954). Economic development with unlimited supplies of labour. The Manchester School, 22(2), |39-191. doi: 10.1 | | |/j.|4679957.1954.tb00021.x

Lo, J., Khoo, T. \& Gilbert, H. (2000). New formations in Asian-Australian cultural politics. Journal of Australian Studies, 24(65), I-12. doi: 10.1080/14443050009387580

Marie-Claude, S. (2007). La situation postcoloniale: les études postcoloniales dans le débat français. Presses de la Fondation nationale des sciences politiques.

Mauss, M. (1968) [1950]. Sociologie et anthropologie. PUF. 
McClelland, D. C. (1964). Business drive and national achievement. In A. Etzioni \& E. Etizioni (Eds.), Social change (pp. 165-178). Basic Books.

Mignolo, W. D. (2000/2012). Local histories/global designs: Coloniality, subaltern knowledges, and border thinking. Princeton University Press.

Mir, A. (2003). The hegemonic discourse of management texts. Journal of Management Education, 27(6), 734-738. doi: 10.1177/ 1052562903257944

Montesquieu, C. D. S. (1748). De l'esprit des lois. Firmin Didot frères.

Nkomo, S. M. (20I I). A postcolonial and anti-colonial reading of "African" leadership and management in organization studies:Tensions, contradictions and possibilities. Organization, 18(3), 365-386. doi: 10.1 I77/ | 3505084 | |39873 |

Parry, B. (1994). Signs of our times: Discussion of Homi Bhabha's the location of culture. Third Text, 8(28-29), 5-24. doi: 10.1080/ 09528829408576499

Parsons, T. (1967). Structure of social action. Free Press.

Prasad, A. (Ed.). (2003). Postcolonial theory and organizational analysis: A critical engagement. Palgrave.

Said, E.W. (1979). Orientalism. Vintage.

Seremani, T.W. \& Clegg, S. (2016). Postcolonialism, organization, and management theory: The role of "epistemological third spaces.' Journal of Management Inquiry, 25(2), 17|-183. doi: 10.1177/ $10564926 \mid 5589973$
Tayeb, M. (200 I). Conducting research across cultures: Overcoming drawbacks and obstacles. International Journal of Cross Cultural Management, I (I), 91-108. doi: 10.1 177//47059580 I I 1009

Wallerstein, I. (1976). The capitalist world economy: Essays. Cambridge University Press.

Weber, M. (1905). The protestant ethic and the spirit of capitalism. Scirbner Press.

Werbner, P. (200I). The limits of cultural hybridity: On ritual monsters, poetic licence and contested postcolonial purifications. Journal of the Royal Anthropological Institute, 7( I), 133-152.

Westwood, R. I. \& Jack, G. (2007). Manifesto for a post-colonial international business and management studies: A provocation. Critical Perspectives on International Business, 3(3), 56-83.

Yousfi H. (20/0). Culture and development: the continuing tension between modern standards and local contexts. In J. P. Platteau \& R. Peccoud (Eds.). Culture, Institutions and development, New insights Into an Old debate (p. 57). Routledge.

Yousfi, H. (20/4). Rethinking hybridity in postcolonial contexts: What changes and what persists? The Tunisian case of Poulina's managers. Organization Studies, 35(3), 393-42I.

Zeitlin, J. \& Herrigel, G. (2000). Americanization and its limits: Reworking US technology and management in post-war Europe and Japan. Work Employment and Society, 43(2), 588-589. 